\title{
Hypopituitarism manifesting after invasive dental treatment in a patient with carcinoma of the tongue: a case report
}

\author{
Yu Ohashi', Naoko Tsunoda', Kei Onodera', Shin lijima', Ikuya Miyamoto', Toshimi Chiba ${ }^{2}$ and Hiroyuki Yamada ${ }^{1 *}$
}

\begin{abstract}
Background: The symptoms of hypopituitarism are not usually discussed in the clinical setting of oral surgery.

Case presentation: We herein report a case of hypopituitarism that became evident after biopsy and extraction of several teeth in a 68-year-old man with tongue cancer. Three days after biopsy, the patient developed nausea and vomiting, and his serum sodium had fallen to $124 \mathrm{mEq} / \mathrm{L}$. His serum cortisol concentration was low. Although the plasma concentration of adrenocorticotropic hormone (ACTH) was within the normal range, ACTH stimulation testing showed a lack of cortisol response. Given these findings, we suspected secondary adrenal insufficiency. To investigate the cause of secondary adrenal insufficiency, MRI of the head was performed, which revealed pituitary gland atrophy. The results of pituitary anterior lobe hormone-stimulation tests were compatible with hypopituitarism. Thirty days after biopsy, partial tongue resection was successfully performed under general anesthesia with perioperative hydrocortisone supplementation.
\end{abstract}

Conclusions: We must be aware of various signs of hypopituitarism when we perform invasive dental treatment.

Keywords: Tongue cancer, Hypopituitarism, Dental treatment, Case report

\section{Background}

Hypopituitarism is a deficiency in one or more trophic hormones, including adrenocorticotropic hormone $(\mathrm{ACTH})$, thyroid-stimulating hormone (TSH), prolactin, growth hormone $(\mathrm{GH})$, and gonadotropins, such as luteinizing hormone (LH) and follicle-stimulating hormone (FSH) [1]. The clinical symptoms depend on the hormone affected and its level of deficiency. Traumatic brain injury and subarachnoid hemorrhage are wellestablished causes of hypopituitarism. However, this risk is not fully recognized by clinicians [2].

\footnotetext{
* Correspondence: yamadah@iwate-med.ac.jp

'Division of Oral and Maxillofacial Surgery, Department of Reconstructive Oral and Maxillofacial Surgery, Iwate Medical University School of Dentistry, 19-1, Uchimaru, Morioka, Iwate 020-8505, Japan

Full list of author information is available at the end of the article
}

The most common type of hypopituitarism is LH and FSH deficiency, which results in amenorrhea in women and decreased libido in men [3]. However, these symptoms are not usually discussed in the clinical setting of oral surgery. Moreover, routine preoperative screening tests generally include no testing of endocrine hormones if patients do not report subjective symptoms. Therefore, untreated hypopituitarism without marked symptoms is easily overlooked.

We experienced a case of hypopituitarism that manifested after invasive dental treatment, a clinical situation rarely documented in the literature. We herein report a case of hypopituitarism that became evident after biopsy and extraction of several teeth in a patient with tongue cancer. 


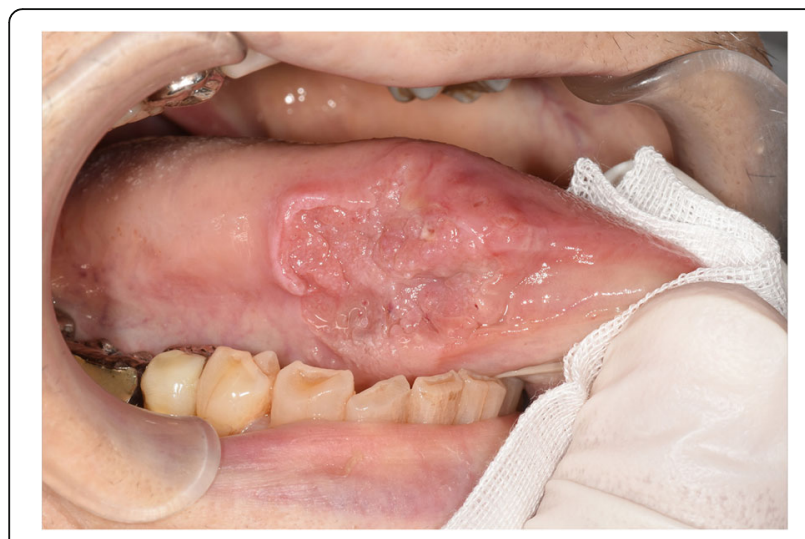

Fig. 1 Photograph showing the lesion on the right edge of the tongue

\section{Case presentation}

A 68-year-old man was referred to the Department of Reconstructive Oral and Maxillofacial Surgery at Iwate Medical University School of Dentistry on May 15, 2017, for diagnosis and treatment of an ulcer on the right side of the tongue. He had first noticed the ulcer about 1 month earlier. The patient's medical history included loss of consciousness resulting from dysautonomia at the age of 32. There was no history of traumatic injury or radiotherapy. Family history was unremarkable. Physical examination revealed facial pallor. In the oral cavity, an ulcer measuring $28 \times$ $18 \mathrm{~mm}$ was present on the right edge of the tongue (Fig. 1). The ulcer was indurated on palpation. There was no cervical lymphadenopathy. The results of blood testing are shown in Table 1. Serum electrolytes were within the normal range.

Magnetic resonance imaging (MRI) was performed with a 3.0-Tesla system (MR750; General Electric Company, Boston, MA, USA). On T1-weighted axial images, the mass on the right edge of the tongue was isointense relative to muscle. On T2-weighted images, slightly increased signal intensity was noted within the mass. On gadolinium-enhanced T1-weighted images, the mass was homogeneous and highly enhanced.

Positron emission tomography was performed with a Discovery PET/CT 600 scanner (General Electric Company, Boston, MA, USA). The image showed abnormal accumulation of fluorodeoxyglucose on the right edge of the tongue at the location of the mass. There was no abnormal accumulation of fluorodeoxyglucose in the lymph nodes or any other organ.

The patient was hospitalized on May 26. On the basis of a clinical diagnosis of tongue cancer (cT2N0M0), biopsy was performed under local anesthesia. During the same procedure, several teeth that were mechanically stimulating the lesion were extracted. The serum sodium concentration was 132 $\mathrm{mEq} / \mathrm{L}$ on the day of biopsy. Three days after biopsy, the patient developed nausea and vomiting, and his serum sodium had fallen to $124 \mathrm{mEq} / \mathrm{L}$. In addition, laboratory examinations (Table 2) showed high serum $\mathrm{TSH}$, low free triiodothyronine $\left(\mathrm{FT}_{3}\right)$, and low free thyroxine $\left(\mathrm{FT}_{4}\right)$. Because antithyroid peroxidase antibodies and antithyroglobulin antibodies were

Table 1 Blood examination on first admission

\begin{tabular}{|c|c|c|c|c|c|c|}
\hline \multirow{2}{*}{$\begin{array}{l}\text { Blood cell count } \\
\text { White blood cell }\end{array}$} & \multicolumn{2}{|r|}{ Blood chemistry } & \multicolumn{4}{|c|}{ Tumor marker } \\
\hline & $5,420 / \mu \mathrm{L}$ & Total protein & $7.2 \mathrm{~g} / \mathrm{dL}$ & SCC & $2.5 \mathrm{ng} / \mathrm{mL}$ & $\uparrow$ \\
\hline Neutrocyte & $2,600 / \mu \mathrm{L}$ & Albumin & $4.7 \mathrm{~g} / \mathrm{dL}$ & & & \\
\hline Lymphocyte & $1,900 / \mu \mathrm{L}$ & Sodium & $140 \mathrm{mEq} / \mathrm{L}$ & & & \\
\hline Monocyte & $260 / \mu \mathrm{L}$ & Potassium & $4.2 \mathrm{mEq} / \mathrm{L}$ & & & \\
\hline Eosinocyte & $540 / \mu \mathrm{L}$ & Chloride & $106 \mathrm{mEq} / \mathrm{L}$ & & & \\
\hline Basocyte & $40 / \mu \mathrm{L}$ & Blood urea nitrogen & $14.9 \mathrm{mg} / \mathrm{dL}$ & & & \\
\hline Red blood cell & $383 \times 10^{4} / \mu \mathrm{L} \quad \downarrow$ & Creatinine & $0.97 \mathrm{mg} / \mathrm{dL}$ & & & \\
\hline Hemoglobin & $11.7 \mathrm{~g} / \mathrm{dL} \downarrow$ & Asoartate aminotransferase & $20 \mathrm{IU} / \mathrm{L}$ & & & \\
\hline Hematocrit & $33.0 \% \quad \downarrow$ & Alanine aminotransferase & $9 \mathrm{IU} / \mathrm{L}$ & $\downarrow$ & & \\
\hline $\mathrm{MCV}$ & $86.2 \mathrm{fL}$ & $\gamma$-glutamyl transpeptidase & $118 \mathrm{IU} / \mathrm{L}$ & $\uparrow$ & & \\
\hline $\mathrm{MCH}$ & $30.5 \mathrm{pg}$ & Total bilirbin & $0.9 \mathrm{mg} / \mathrm{dL}$ & & & \\
\hline $\mathrm{MCHC}$ & $35.4 \mathrm{~g} / \mathrm{dL} \uparrow$ & Direct bilirbin & $0.2 \mathrm{mg} / \mathrm{dL}$ & & & \\
\hline \multirow[t]{6}{*}{ Platelet } & $12.4 \times 10^{4} / \mu \mathrm{L}$ & Indirect bilirbin & $0.7 \mathrm{mg} / \mathrm{dL}$ & $\uparrow$ & & \\
\hline & & Alkaline phosphatase & $353 \mathrm{IU} / \mathrm{L}$ & $\uparrow$ & & \\
\hline & & Serum iron & $66 \mu \mathrm{g} / \mathrm{dL}$ & & & \\
\hline & & Unsaturated iron binding capacity & $151 \mu \mathrm{g} / \mathrm{dL}$ & & & \\
\hline & & Total iron binding capacity & $217 \mu \mathrm{g} / \mathrm{dL}$ & $\downarrow$ & & \\
\hline & & C-reactive protein & $0.66 \mathrm{mg} / \mathrm{dL}$ & $\uparrow$ & & \\
\hline
\end{tabular}

$M C V$ mean corpuscular volume, $M C H$ mean corpuscular hemoglobin, $M C H C$ mean corpuscular hemoglobin concentration, $S C C$ squamous cell carcinoma, $f L$ femto litre, $p g$ pico gram, IU international unit, $n g$ nano gram 
Table 2 Laboratory findings

\begin{tabular}{lrllll}
\hline Endocrinology & & & Urinalysis & \\
Serum cortisol & 1.88 & $\mu \mathrm{g} / \mathrm{dL}$ & $\downarrow$ & Urine osmolarity & $421 \mathrm{mOSM} / \mathrm{L} \uparrow$ \\
$\mathrm{TSH}$ & 15.18 & $\mu \mathrm{IU} / \mathrm{mL}$ & $\uparrow$ & Urine sodium & $123 \mathrm{mEq} / \mathrm{L}$ \\
$\mathrm{FT}_{4}$ & $0.53 \mathrm{ng} / \mathrm{dL}$ & $\downarrow$ & & \\
$\mathrm{FT}_{3}$ & $1.35 \mathrm{pg} / \mathrm{mL}$ & $\downarrow$ & & \\
& & & & & \\
Auto antibody & & & & \\
anti-TPO antibody & $344.2 \mathrm{IU} / \mathrm{mL}$ & $\uparrow$ & & \\
anti-TG antibody & $226.3 \mathrm{IU} / \mathrm{mL}$ & $\uparrow$ & & \\
& & & & \\
Blood chemistry & & & & \\
Serum osmolarity & $228 \mathrm{mOSM} / \mathrm{L}$ & $\downarrow$ & & \\
\hline
\end{tabular}

$\overline{T S H}$ thyroid stimulating hormone, FT4 free thyroxine, FT3 free triiodothyronine, TPO thyroid peroxidase, TG thyroglobulin, IU international unit, $n g$ nano gram, $p g$ pico gram, OSM osmole

confirmed as positive, a diagnosis of Hashimoto thyroiditis was made. Administration of levothyroxine sodium $\left(\mathrm{LT}_{4}\right)$ was started. However, nausea and vomiting were not controlled. The findings of low serum cortisol, low serum sodium, and high urine osmolality raised suspicion of acute adrenal insufficiency. The patient was transferred to the medical department and administration of dexamethasone at $0.25 \mathrm{mg}$ per day was started instead of $\mathrm{LT}_{4}$. The plasma ACTH concentration $(8.8 \mathrm{pg} / \mathrm{mL})$ was within the normal range. On June 7, ACTH stimulation testing was performed. The plasma cortisol concentration before the test was $1.8 \mu \mathrm{g} / \mathrm{dL}$. Plasma cortisol concentrations 30 and 60 min after administration of corticotropin $(250 \mu \mathrm{g})$ were $4.0 \mu \mathrm{g} / \mathrm{dL}$ and $4.8 \mu \mathrm{g} / \mathrm{dL}$, respectively. On the basis of these findings, we suspected secondary adrenal insufficiency. On June 13, administration of $\mathrm{LT}_{4}$ was restarted for the treatment of hypothyroidism. To investigate the cause of secondary adrenal insufficiency, MRI of the head was performed, which revealed pituitary gland atrophy (Fig. 2). The results of pituitary anterior lobe hormone-stimulation tests are listed in Table 3. These results were compatible with hypopituitarism. The patient's severe consciousness disorder, which scored 3 on the Glasgow Coma Scale 14 days after biopsy, gradually improved, with full recovery on day 20 after biopsy. Thirty days after biopsy, partial tongue resection was successfully performed under general anesthesia with perioperative hydrocortisone supplementation. The histopathological diagnosis was squamous cell carcinoma of the tongue. The postoperative course was uneventful. The perioperative clinical course is summarized in Fig. 3.

\section{Discussion and conclusions}

Most cases of hypopituitarism arise from destructive processes directly involving the anterior pituitary, including tumors, traumatic brain injury, Sheehan syndrome, apoplexy, inflammatory disorders, and radiation [1]. Brain injury resulting from traumatic thoracic injury [4], autoimmune disease [5], and

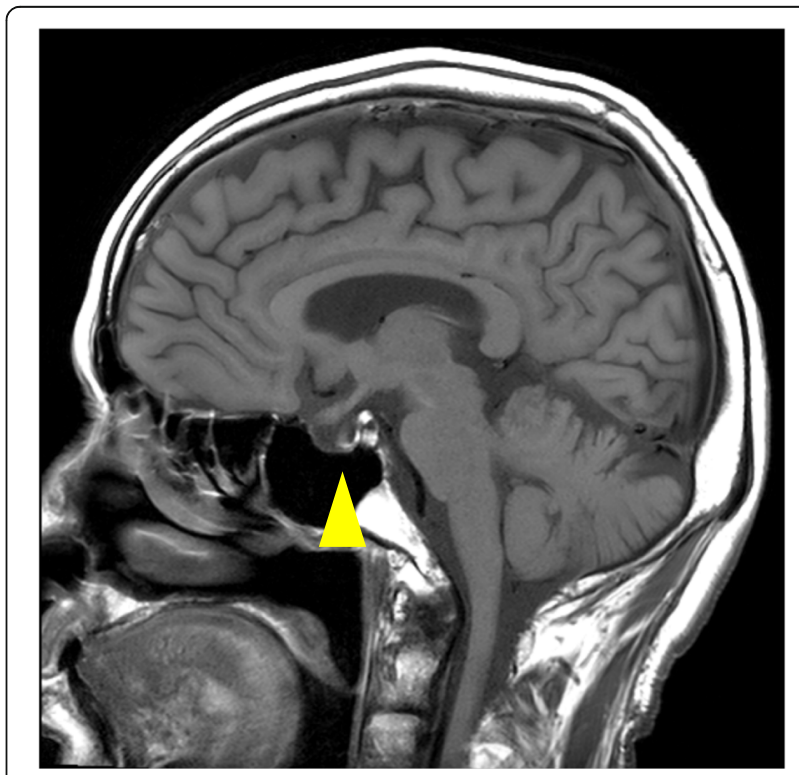

Fig. 2 Brain MRI findings. T2-weighted sagittal image showing atrophic pituitary gland (arrowhead) 
Table 3 Anterior pituitary function test

\begin{tabular}{|c|c|c|c|c|c|c|c|c|c|}
\hline & normal value & pre loading & $15 \mathrm{~min}$ & $30 \mathrm{~min}$ & $45 \mathrm{~min}$ & $60 \mathrm{~min}$ & $90 \mathrm{~min}$ & normal reaction & decision \\
\hline $\mathrm{ACTH}(\mathrm{pg} / \mathrm{mL})$ & 756 & 9.1 & - & 15.1 & - & 21.2 & 20.8 & $\begin{array}{l}\text { more than diploid number } \\
\text { (30-60 min) }\end{array}$ & hyporesponsiveness susp \\
\hline Cortisol $(\mu \mathrm{g} / \mathrm{dL})$ & $4 \quad 23.3$ & 4.4 & - & 4.8 & - & 5.1 & 5.1 & more than 18 (60 min) & hyporesponsiveness \\
\hline TSH ( $\mu \mid \mathrm{U} / \mathrm{mL})$ & $0.35 \quad 4.94$ & 1.29 & - & 2.98 & - & 2.77 & 2.51 & $3.5-15$ (30 min) & hyporesponsiveness \\
\hline PRL (ng/mL) & $1.4 \quad 14.6$ & 2.7 & - & 4.4 & - & 4.1 & 3.7 & $\begin{array}{l}\text { more than diploid number } \\
\text { (15-30 min) }\end{array}$ & hyporesponsiveness \\
\hline $\mathrm{LH}(\mathrm{mlU} / \mathrm{mL})$ & $0.7 \quad 24.2$ & 0.6 & - & 1.5 & - & 2.1 & 2.1 & five times the value (30 min) & hyporesponsiveness \\
\hline $\mathrm{FSH}(\mathrm{mlU} / \mathrm{mL})$ & $2.7 \quad 56.7$ & 1.8 & - & 2.0 & - & 2.3 & 2.4 & $1.5-2.5$ times the value (30 $\mathrm{min})$ & hyporesponsiveness \\
\hline $\mathrm{GH}(\mathrm{ng} / \mathrm{mL})$ & $0.68 \quad 8.7$ & 0.40 & 1.17 & 0.98 & 0.70 & 0.49 & - & more than 9 (15-30 $\mathrm{min})$ & hyporesponsiveness \\
\hline
\end{tabular}

ACTH adrenocrticotropic hormenoe, TSH thyroid-stimulating hormone, $P R L$ prolactin, $L H$ luteinizing hormone, FSH follicle-stimulating hormone, GH growth hormone, $p g$ pico gram, IU international unit, ng: nano gram

metastasis to the pituitary [6] are additional reported causes of hypopituitarism. Recently, immune checkpoint inhibitors have been used to treat various types of cancer. With increased use of these inhibitors, physicians should be aware of the possibility of immune checkpoint inhibitor-induced hypophysitis. Cytotoxic T-lymphocyte antigen (CTLA)-4 is expressed in the pituitary gland; anti-CTLA-4 antibodies were reported to induce hypophysitis [7]. Furthermore, anti-programmed cell death (PD)-1 and anti-PD-ligand 1 antibodies have been reported to induce hypophysitis, leading to pituitary atrophy [8]. Therefore, we must be aware of various signs of hypopituitarism when we perform invasive dental treatment.
The anterior lobe of the pituitary has high functional reserve; therefore, more than $75 \%$ of the parenchyma must be lost before symptoms of hypopituitarism are seen [1]. In the present case, anterior lobe hormone-stimulation tests revealed hyporeactivity of ACTH, TSH, LH, FSH, prolactin and GH. MRI revealed pituitary atrophy. These results and the medical history of loss of consciousness indicate that the patient's hypopituitarism might have been gradually progressive before dental treatment. The invasive dental treatment might have decreased the functional reserve of the pituitary, resulting in clinical symptoms.

It is rare that an invasive medical procedure results in diagnosis of hypopituitarism. To the best of our

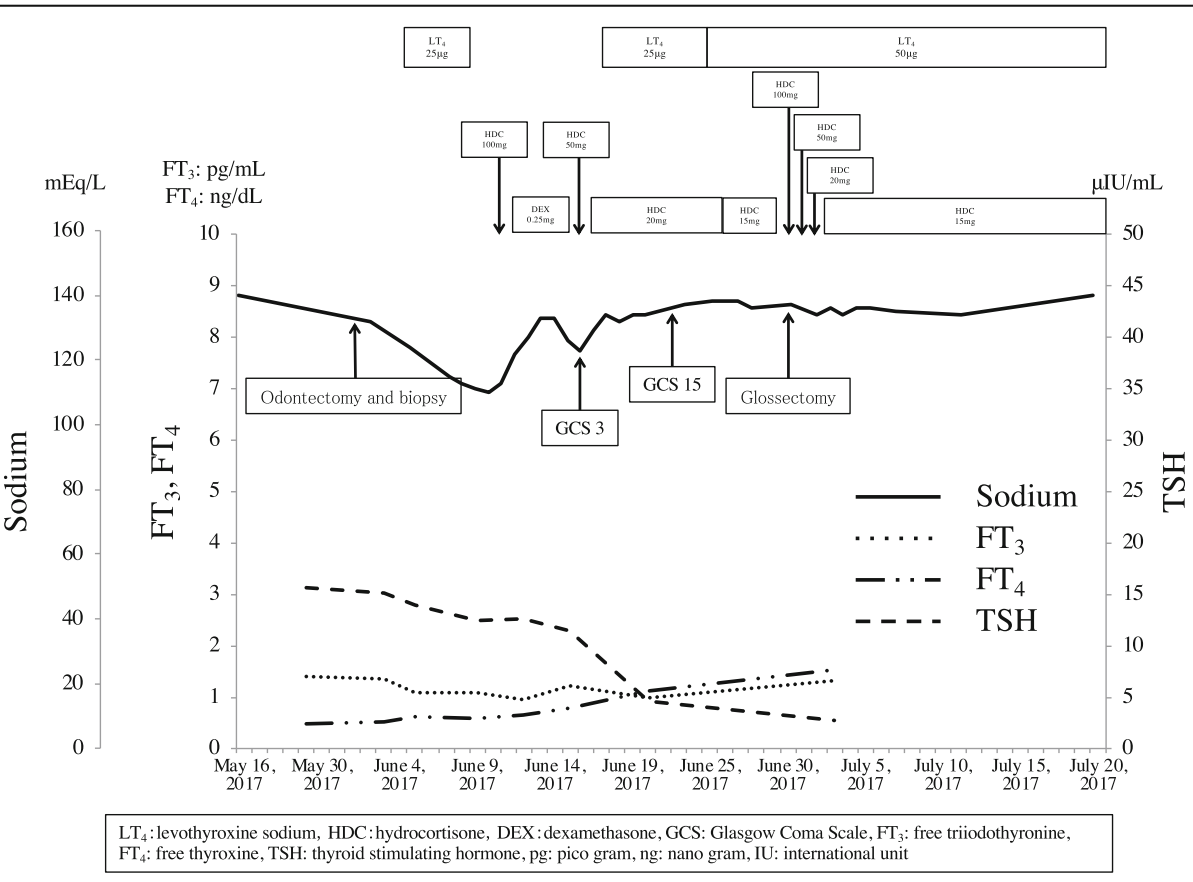

Fig. 3 Clinical course 
knowledge, two such cases have been reported in the Japanese literature $[9,10]$. In these cases, food intake decreased as a result of invasive medical procedures, and the stress of hospitalization increased the relative cortisol requirement. These factors caused adrenal insufficiency to become evident. Hypopituitarism with resulting adrenal insufficiency causes malaise, fatigue, nausea, vomiting, weight loss, and muscle weakness. Adrenal crisis is biochemically characterized by hyponatremia and hypoglycemia in patients with hypopituitarism. Hyperkalemia is not present in hypopituitary patients because they do not have mineralocorticoid deficiency, unlike patients with primary adrenal insufficiency [11]. Surgical stress can result in an adrenal crisis, with shock or disturbed consciousness as symptoms. These symptoms are life-threatening; therefore, urgent administration of hydrocortisone is required [12]. In the present case, the patient's food intake decreased after invasive dental treatment, resulting in worsening hyponatremia. We attributed the patient's symptoms to severe pain after dental treatment; however, these symptoms were caused by hypopituitarism with adrenal insufficiency.

Treatment of hypopituitarism is classified as causal or symptomatic. In the present case, neither pituitary surgery nor radiation had been performed, and the cause of hypopituitarism was not obvious; therefore, symptomatic treatment was selected. Because hypopituitarism was diagnosed before the treatment of tongue cancer, adequate perioperative hydrocortisone supplementation was administered. As a result, adrenal crisis was avoided during surgery for tongue cancer.

In conclusion, when decreased appetite, malaise, and fatigue occur after invasive treatments, the possibility of masked hypopituitarism should be considered.

\begin{abstract}
Abbreviations
MRI: Magnetic resonance imaging; ACTH: Adrenocorticotropic hormone; PET: Positron emission tomography; CT: Computed tomography; TSH: Thyroid-stimulating hormone; TPO: Thyroid peroxidase; TG: Thyroglobulin; $\mathrm{FT}_{3}$ : Free triiodothyronine; $\mathrm{FT}_{4}$ : Free thyroxine; PRL: Prolactin; LH: Luteinizing hormone; FSH: Follicle-stimulating hormone; $\mathrm{GH}$ : Growth hormone; $\mathrm{LT}_{4}$ : Levothyroxine sodium; HDC: Hydrocortisone; DEX: Dexamethasone; GCS: Glasgow coma scale; CTLA: Cytotoxic Tlymphocyte antigen; PD: Programmed cell death; MCV: Mean corpuscular volume; MCH: Mean corpuscular hemoglobin; MCHC: Mean corpuscular hemoglobin concentration; SCC: Squamous cell carcinoma; fL: femto litre; pg: pico gram; IU: International unit; ng: nano gram; OSM: Osmole
\end{abstract}

\section{Acknowledgments}

We thank Yuki Matsuura of the Department of Internal Medicine, Iwate Medical University, for the treatment of adrenal insufficiency. We also thank Rebecca Tollefson, DVM, from Edanz Group (https://en-author-services. edanzgroup.com/) for editing a draft of this manuscript.

\section{Authors' contributions}

YO performed surgery and drafted the manuscript. NT and KO managed hospitalization and collected clinical data. SI diagnosed carcinoma of the tongue and conducted outpatient management. IM suggested the treatment method. TC made medical decisions and provided treatments. HY provided comprehensive judgment and assisted in editing the final version of the manuscript. All authors read and approved the final version of the manuscript prior to submission.

Funding

Not applicable.

Availability of data and materials

Not applicable.

Ethics approval and consent to participate

Not applicable.

\section{Consent for publication}

Written informed consent was obtained from the patient for publication of this case report and any accompanying images.

\section{Competing interests}

Not applicable.

\section{Author details}

${ }^{1}$ Division of Oral and Maxillofacial Surgery, Department of Reconstructive Oral and Maxillofacial Surgery, Iwate Medical University School of Dentistry, 19-1, Uchimaru, Morioka, Iwate 020- 8505, Japan. ${ }^{2}$ Division of Internal Medicine of Dentistry, Department of Oral medicine, Iwate Medical University School of Dentistry, 19-1, Uchimaru, Morioka 020-8505, Japan.

Received: 16 April 2019 Accepted: 19 March 2020

Published online: 15 April 2020

\section{References}

1. Maitra A. In: Kumar V, Abbas AK, Aster JC, editors. The endocrine system, in Robbins and Cotran Pathologic basis of disease. 9th ed. Philadelphia: Elsevir Saunders; 2015. p. 1080-1.

2. Schneider HJ, Aimaretti G, Kreitschmann-Andermahr I, Stalla GK, Ghigo E. Hypopituitarism. Lancet. 2007;369(9571):1461-70.

3. Tanriverdi F, Dokmetas HS, KebapcI N, Kilicli F, Atmaca H, Yarman S, Ertorer ME, Erturk E, Bayram F, Tugrul A, Culha C, Cakir M, Mert M, Aydin H, Taskale M, Ersoz N, Canturk Z, Anaforoglu I, Ozkaya M, Oruk G, Hekimsoy Z, Kelestimur F, Erbas T. Etiology of hypopituitarism in tertiary care institutions in Turkish population: analysis of 773 patients from Pituitary Study Group database. Endocrine. 2014:47(1):198-205.

4. Gilis-Januszewska A, Kluczyński Ł, Wilusz M, Pantofliński J, Turek-Jabrocka R, Pach D, Hubalewska-Dydejczyk A. Pituitary insufficiency following traumatic thoracic injury in an adolescent male patient: A case report and literature review. Medicine. 2017;96(44):e8406.

5. Grugni G, Crinò A, De Bellis A, Convertino A, Bocchini S, Maestrini S, Cirillo P, De Lucia S, Delvecchio M. Italian Autoimmune Hypophysitis Network Study and of the Genetic Obesity Study Group of the Italian Society of Pediatric Endocrinologyand Diabetology (ISPED). Autoimmune pituitary involvement in Prader-Willi syndrome: new perspective for further research. Endocrine. 2018;62(3):733-6.

6. Wendel C, Campitiello M, Plastino F, Eid N, Hennequin L, Quétin P, Longo R. Pituitary Metastasis from Renal Cell Carcinoma: Description of a Case Report. Am J Case Rep. 2017;18:7-11.

7. Caturegli P, Di Dalmazi G, Lombardi M, Grosso F, Larman HB, Larman T, Taverna G, Cosottini M, Lupi I. Hypophysitis Secondary to Cytotoxic TLymphocyte-Associated Protein 4 Blockade: Insights into Pathogenesis from an Autopsy Series. Am J Pathol. 2016;186(12):3225-35.

8. Kanie K, Iguchi G, Bando H, Fujita Y, Odake Y, Yoshida K, Matsumoto R, Fukuoka H, Ogawa W, Takahashi Y. Two Cases of Atezolizumab-Induced Hypophysitis. J Endocr Soc. 2017;2(1):91-5.

9. Asakawa S, Kawasaki S, Onishi T, Sato M, Takagi M. Diagnosis of isolatedACTH deficiency in patientwith Type 2 diabetes after surgery for esophageal cancer. Inter Med. 2010;106(5):949-52 (Japanese). 
10. Fujita N, Minowa T, Shimizu K, Tanaka K, Okubo Y. A case of isolated ACTH deficiency complicated by Hashimoto's thyroiditis detected following hypoglycemic attack associated with gastric cancer. Intern Med. 2009;104(5): 956-9 (Japanese).

11. Charmandari E, Nicolaides NC, Chrousos GP. Adrenal insufficiency. Lancet. 2014;383:2152-67.

12. Rushworth RL, Torpy DJ, Falhammar H. Adrenal crises: perspectives and research directions. Endocrine. 2017;55:336-45.

\section{Publisher's Note}

Springer Nature remains neutral with regard to jurisdictional claims in published maps and institutional affiliations.

Ready to submit your research? Choose BMC and benefit from:

- fast, convenient online submission

- thorough peer review by experienced researchers in your field

- rapid publication on acceptance

- support for research data, including large and complex data types

- gold Open Access which fosters wider collaboration and increased citations

- maximum visibility for your research: over $100 \mathrm{M}$ website views per year

At $B M C$, research is always in progress.

Learn more biomedcentral.com/submissions 